\title{
A Tribute to Bruce Malfait
}

\author{
BY J. PAUL DAUPHIN
}

The Ocean Drilling Program (ODP) was one of the largest and most successful programs of international marine geoscience ever undertaken. It was one in a series of scientific drilling programs that owed its huge success to the participation and contributions of many gifted and dedicated individuals. Many will agree, however, that one person in particular stood out as having played a major role in shaping the nature of this valuable program and its resulting successes. That person was Bruce Malfait, ODP Program Director at the U.S. National Science Foundation (NSF). NSF was the lead agency, which managed ODP on behalf of the participating international community. Bruce was the perfect choice for the NSF job when he took the reins of ODP in its early days. He had already had a long and exemplary career at NSF, which provided him

\section{J. Paul Dauphin (pdauphin@charter.} net) started at NSF in 1991 as Associate Program Director, Ocean Drilling Programs. He remained in that position until Bruce became a Section Head for Ocean Sciences, at which time Paul became Program Director, Ocean Drilling Programs. Paul is now enjoying his retirement in North Carolina. with a comprehensive overview and indepth knowledge of marine geological and geophysical research at home and abroad. Bruce's immediate prior position at NSF had been as the Director of the Marine Geology and Geophysics Program (MG\&G) in the Division of Ocean Sciences. Bruce was responsible for funding much of the MG\&G research in the United States. By virtue of this experience, he was well suited to be a leader of the program that provided such a critical and unique asset to the study of marine geology.

Bruce's integrity, dedication, hard work, and strong ethics are some of the many virtues from which ODP and the scientific community have benefited. I can speak with some authority on the subject, having known Bruce for his entire career-from the years we were graduate students together, to more recent times at NSF when he was a colleague and supervisor. I can safely say that anyone who knows Bruce knows of his deep love for the Earth sciences and his concern for the health and vitality of programs in this discipline. Anyone who has served on an ODP or MG\&G proposal review panel knows that the number of high-quality, fundable proposals far outnumbers the available resources to support them all. This is where Bruce's unique qualities were so valuable. As he struggled with funding decisions, he always strived to seek the proper balance, ultimately optimizing the strength and vitality of the Earth sciences. Bruce's almost eidetic memory of historical MG\&G funding allowed him to view the science from a special perspective. This perspective was a real asset in maintaining funding balance. Rejuvenation and vitality of the field was important to Bruce. He was constantly searching for exceptional young talent that could flourish given the opportunity. Bruce strongly felt that diversity was strength and strongly advocated for it. He kept a keen eye out for promising, innovative, and sometimes risky ideas.

Bruce was a consummate bureaucrat and knew how to get things done in a government setting. Every few years it was Bruce's task to argue before the U.S. National Science Board for the continuation of the ODP. He did this with such skill that the Board invariably gave its approval for the continued funding of the program. It did not hurt that the ODP was so successful, but in an environment where the Board had many 


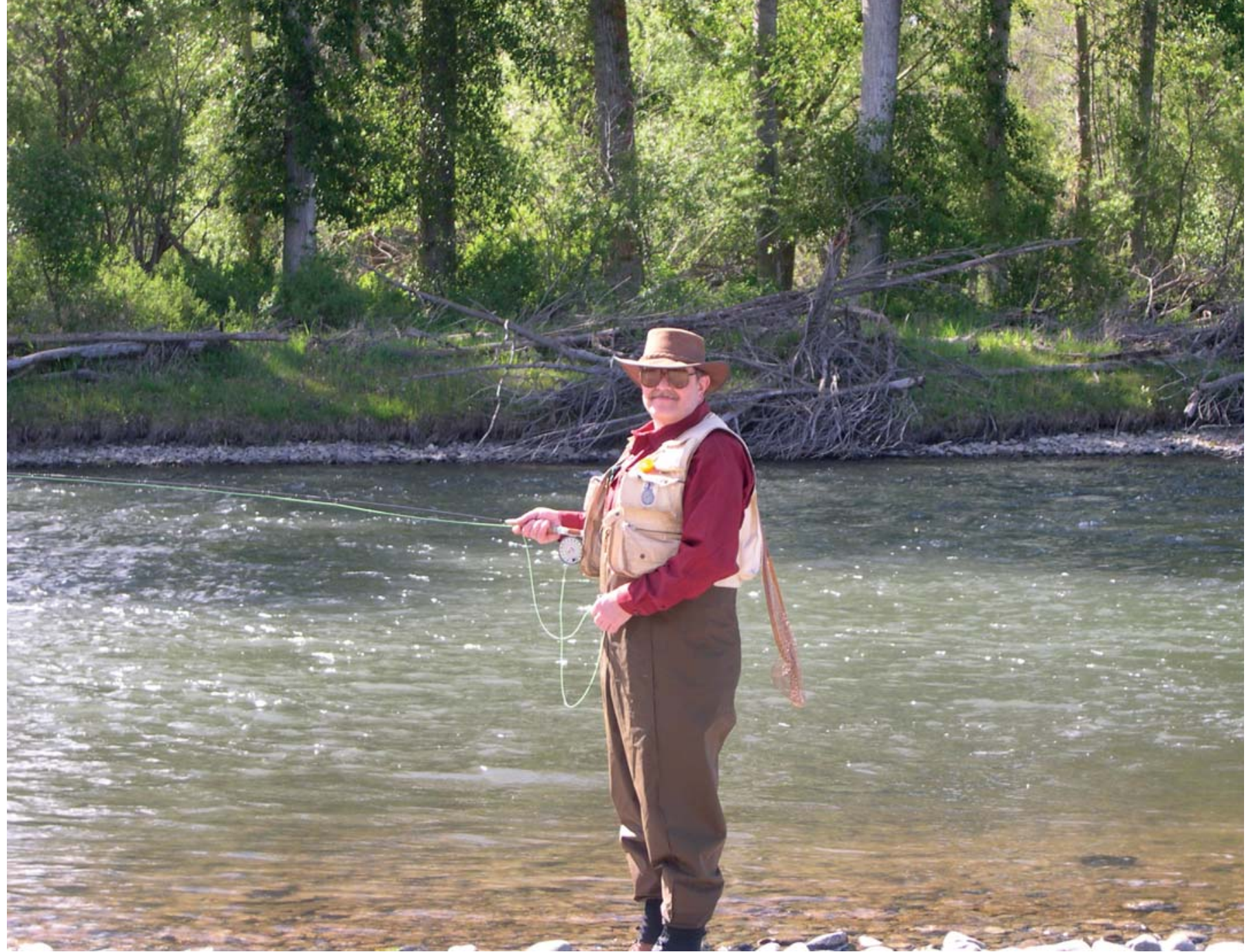

demands for limited resources, Bruce's ability to convey the excitement of ODP made a difference. When the U.S. Government shut down for lack of a spending bill, Bruce successfully navigated the red tape required to keep the JOIDES Resolution at sea and working. Bruce's work ethic is legend for those of us who worked with him. Hardly a day went by that Bruce was not in the office. The only difference between weekdays and weekends was that Bruce's workday was a little shorter on weekends.

In the last few years, as ODP was coming to a mandated end, Bruce devoted himself to making the proposed followon Integrated Ocean Drilling Program (IODP) a reality. Bruce devoted innu- merable hours drafting and negotiating terms of agreement between the Japanese agency, which would co-lead IODP, and NSF. Bruce welcomed the challenge to develop the mechanisms that would allow IODP to happen. He also worked diligently with the Japanese to develop agreements with the European scientific community that would allow them to be a major partner in this new venture. These agreements were designed to maximize participation of the entire international scientific community. Bruce's overriding purpose was to ensure that the science of the program would be optimized.

There are many told and untold stories that attest to the enormous influence
Bruce has had on the science to which he was so devoted throughout his career and to the scientific community he so loyally served. That career ended recently so that Bruce could pursue full time his other abiding love-a lust—for flyfishing. Bruce has certainly earned the right to move on and indulge this other passion full time. We wish him well in that pursuit. Filling the huge vacancy he leaves behind will be a challenge, but if only a fraction of the talent and devotion that Bruce brought to the position is realized, science and the scientific community will be well served.

Bruce, congratulations on your retirement! 届 